\title{
Weather Forecasting at BMKG Office Lumajang City Using Markov Chain Method
}

\author{
Ummi Masrurotul Jannah*, Mohamat Fatekurohman \\ Department of Mathematics, Faculty of Mathematics and Natural Sciences, University of Jember, Indonesia \\ "Corresponding author. Email: masrurohmj@gmail.com
}

\begin{abstract}
Weather forecasting is one of the important factors in everyday life, because it can affect the activities carried out by the community. Weather forecasting refers to a series of activities carried out to produce a set of information about weather conditions. One method that can be used to model these uncertain conditions is the Markov chain. The Markov chain is a random process in which all information about the future is contained in the present state. In this study the authors use daily weather data that occurs on December 22- 282020.
\end{abstract}

Keywords: Markov chain, Weather conditions, Weather forecasting.

\section{INTRODUCTION}

Weather forecasting is one of the important factors in everyday life, because it can affect the activities carried out by the community [1]. Technological science that is growing is very possible to be used in terms of weather forecasting, in its calculation weather forecasts are determined by several parameters that greatly affect weather conditions, these parameters are temperature, rainfall, evaporation, solar radiation, air pressure, humidity and wind. The Meteorology, Climatology and Geophysics Agency (BMKG) obtains parameter values from thermometer observation equipment, rain gauges, for evaporation, for solar radiation, barometer, hygrometer [2].

The rapid growth of data accumulation causes a lot of data to be collected but cannot be processed properly so that it does not obtain good information either. As a forecasting method, Markov chains can be used to predict changes in time that will come in the variables in the past. The Markov chain has the special property that the conditional transition probability of future events depends only on the current event and is independent of the events that have passed. In Markov Chain, we need a transition probability matrix to move from one state to the next. Markov Chain method is a combination of two methods, namely Fuzzy Time series and Markov Chain. Fuzzy Time series is a scientific concept proposed by Song and Chissom which is used to solve forecasting problems with historical data in the form of linguistic values [3].

One method that can be used in modeling these uncertain conditions is the Markov chain. Some fields in everyday life that can still apply the Markov Chain include economics (customer transfer), science and technology and also play (snakes and ladders) and health (development of a disease).

Weather prediction refers to a series of activities carried out to produce a collection of information about climatic conditions and their elements. This information is useful in many ways, one of which is to forecast rainfall which has a large effect on all kinds of life activities. For example, farmers really need information about the rainy season forecast so that they can better prepare for the planting season. Other fields that require weather and climate information or predictions include: tourism, fisheries, shipping, plantations, forestry, building construction, regional planning, and health [4].

The Markov chain is a random process in which all information about the future is contained in the present state (i.e. one does not need to examine the past to determine the future). To be more precise, the basic 
concept of Markov analysis is the state of the system or transition state, the nature of this process is that if it is known that the process is in a certain state, then the chance of developing the process in the future only depends on the current state and does not depend on the previous state. or in other words a Markov chain is a series of event processes where the conditional probability of future events depends on current events.

As a basis for Markov chain analysis, it is necessary to first know about the stochastic process which studies the sequence of events whose occurrence is based on certain probabilities which are arranged more easily in the form of a matrix called the transition probability matrix [5].

The transition probability matrix is a matrix that contains information that governs the movement of the system from one state to another. The transition probability matrix is often called a stochastic matrix because the transition probability is constant and does not depend on time $t$, where is the transition probability one step moving from state to state [6].

Based on the explanation above, the researchers are interested in conducting research on models to predict the occurrence of rain and completing several examples of cases of its application using the Markov Chain, with the aim of research to determine the calculation process and examples of cases of application of the Markov Chain model on weather predictions and weather conditions that will occur in the next period especially in the city of Lumajang.

\section{RESEARCH METHOD}

This research is carried out at the Office of the Meteorology, Climatology and Geophysics Agency Lumajang city. The data used in this study is secondary data, namely daily weather data that occurred in Lumajang City on December 22- 28 2020. The data analysis method in this study the steps taken by the author is to make a daily weather table then divided into four weather conditions, namely Sunny, Cloudy, Light Rain and Rain. both current and previous, tables the change in weather from one weather condition to another and determines the transition probability matrix $(P)$.

\section{RESULTS AND DISCUSSION}

\subsection{Data Description}

The data of this research is daily weather data on January December 22- 282020 in Lumajang City. The weather data criteria are based on data categories, namely Sunny, Cloudy, and Light Rain, Rain. For daily weather data, it is categorized again based on the time of weather changes, namely in the morning, afternoon, evening and night. Below are monthly weather data and daily weather.

Based on Table 1, the daily weather data is quite varied, but the most dominant weather occurs in one week on Tuesday 22 to 28 December 2020 both in the morning, afternoon, evening and night is light rain and rain.

\subsection{Modeling Weather Data}

Modeling weather data Into a Markov Chain Transition Matrix From the daily weather data above, the total weather is calculated based on categories that occur in one day.

Table 2. Number of daily weather changes

\begin{tabular}{lcccc}
\hline Change & Bright & Cloudy & Light Rain & Rain \\
\hline Tuesday & 1 & - & 1 & 2 \\
\hline Wednesday & - & 1 & - & 3 \\
\hline Thursday & - & 1 & 2 & 1 \\
\hline Friday & - & - & 2 & 2 \\
\hline Saturday & - & 1 & 2 & 1 \\
\hline Sunday & - & - & 1 & 3 \\
\hline Monday & 1 & 1 & 2 & - \\
\hline Tuesday & - & - & 2 & 2 \\
\hline Wednesday & - & - & 3 & 1 \\
\hline Sum & 2 & 4 & 15 & 15 \\
\hline & & & &
\end{tabular}

Based on Table 2, it is obtained from the number of daily weather which is calculated based on the categories that occur in one day, namely morning, afternoon, evening and night. For example the weather that occurs on Tuesday, sunny in the afternoon, light rain during the day and rain in the morning and evening.

Table 1. Monthly weather data on 22-28 Desember 2020

\begin{tabular}{|c|c|c|c|c|c|}
\hline Day & Date & Morning & Afternoon & Evening & Night \\
\hline Tuesday & $22 / 12 / 2020$ & Rain & Light rain & Bright & Rain \\
\hline Wednesday & $23 / 12 / 2020$ & Rain & Rain & Cloudy & Rain \\
\hline Thursday & $24 / 12 / 2020$ & Light rain & Light rain & Cloudy & Rain \\
\hline Friday & $25 / 12 / 2020$ & Rain & Light rain & Light rain & Rain \\
\hline Saturday & $26 / 12 / 2020$ & Rain & Cloudy & Light rain & Light rain \\
\hline Sunday & $27 / 12 / 2020$ & Rain & Rain & Light rain & Rain \\
\hline Monday & $28 / 12 / 2020$ & Cloudy & Bright & Light rain & Light rain \\
\hline
\end{tabular}


From the weather data, it is obtained, $P_{i j}=1,2,3,4$ and $j=1,2, \ldots, 7$ that is the transition probability from state $i$ to state $j . P_{i}$ it is obtained by dividing the change in weather conditions $\mathrm{j}$ by the sum of changes in the weather I to weather $j$ is denoted as $t_{i j}$ with $i=1,2,3,4$ and $j=1,2$, $\ldots, 7$.

$$
p_{i j}=\frac{t_{i j}}{\sum_{i}^{4} t_{i j}}
$$

For weather changes from sunny to sunny conditions, the proportion of changes in weather changes from sunny to cloudy conditions, the proportion of displacement is equal to and so on. The proportion of changes in each weather condition can be seen in the table below.

Table 3. Transition matrix

\begin{tabular}{lcccc} 
Probability & Bright & Cloudy & Light Rain & Rain \\
\hline Bright & 0 & 0 & 0,5 & 0,5 \\
\hline Bright & 0 & 0,25 & 0,5 & 0,25 \\
\hline Bright & 0 & 0 & 0,25 & 0,75 \\
\hline Bright & 0,25 & 0,25 & 0,5 & 0 \\
\hline
\end{tabular}

Based on the Table 3 above, the weather in Lumajang City can be estimated as follows:

a. If today is sunny, tomorrow will have a $0 \%$ chance of sunny weather, $0 \%$ cloudy, $50 \%$ light rain, and $50 \%$ rain.

b. If it is cloudy today, tomorrow will have a $0 \%$ chance of sunny weather, $25 \%$ cloudy, $50 \%$ light rain, and $25 \%$ rain.

c. If it rains today, tomorrow will have a $0 \%$ chance of sunny weather, $25 \%$ cloudy, $0.75 \%$ light rain, and $25 \%$ rain.

d. If it rains today, tomorrow it will have a $0 \%$ chance of sunny weather, $0 \%$ cloudy, $50 \%$ light rain, and $50 \%$ rain.

\subsection{Weather Prediction Using Markov Chain Model}

The state of the time-dependent system can be determined using the variable transition probability matrix and the initial state matrix. If $\mathrm{P}(\mathrm{n})=\mathrm{P}(\mathrm{n})$ as a matrix of size mxm with elements $P_{i j}^{(n)}$.

$$
P^{(n)}=P^{(n)}, n=1,2, \ldots
$$

For example (is a sized matrix) with elements $P_{j}^{(n)}$, for $P_{0}$ is the initial probability of the state of the system, then $P_{(n)}$ $=P_{0} P(n), \mathrm{n}=1,2, \ldots$ The above means that the probability of the state of the system at time is obtained by multiplying the initial probability matrix by the time transition matrix

Based on the weather change transition matrix above, it is clear that the weather forecast can be solved with markov.

- The next process only depends on the current process.

- Discrete time and discrete population.

- Stationary from time to time there are 4 categories, $1=$ sunny, $2=$ cloudy, $3=$ rainy, and $4=$ light rain before Friday we consider 0 , so to predict some weather that will occur during the next 1 week can be calculated based on the steady state matrix $\pi(0)$.

$$
\pi_{j}=\sum_{i}^{7} \pi_{i} P_{i j}, i=j=1,2,3,4
$$

A. If it rains on Friday, then the weather prediction is per

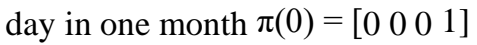

Table 4. The daily weather data

\begin{tabular}{lllll}
\hline Probability & Bright & Cloudy & Light Rain & Rain \\
\hline Saturday & 0,25 & 0,25 & 0,5 & 0 \\
\hline Sunday & 0 & 0,0625 & 0,375 & 0,5625 \\
\hline Monday & 0,1406 & 0,1562 & 0,4062 & 0,2968 \\
\hline Tuesday & 0,0742 & 0,1132 & 0,3984 & 0,414 \\
\hline Wednesday & 0,1035 & 0,1318 & 0,4003 & 0,3642 \\
\hline Thursday & 0,0911 & 0,124 & 0,3999 & 0,385 \\
\hline Friday & 0,0962 & 0,1273 & 0,4 & 0,3765 \\
\hline
\end{tabular}

Based on Table 4, the daily weather data is quite varied, but the most dominant weather occurs in one week, namely sunny with an average probability of above 0.1079 or $10.79 \%$, cloudy with an average probability of above 0.1378 or $13.78 \%$, light rain with an average probability above 0.4114 or $41.14 \%$ and rain with an average probability of 0.3427 or $34.27 \%$.

B. If there is light rain on Friday, the weather predictions per day in the next 1 week are $\pi(0)=\left[\begin{array}{llll}0 & 0 & 1 & 0\end{array}\right]$

If there is light rain on Friday, the matrix $\pi(0)=\left[\begin{array}{ll}0 & 0\end{array}\right.$ 10 ] can be presented in the following Table 5.

Table 5. Daily weather data obtained varies

\begin{tabular}{lllll}
\hline Probability & Bright & Cloudy & Light Rain & Rain \\
\hline Saturday & 0 & 0 & 0,25 & 0,75 \\
\hline Sunday & 0,188 & 0,1875 & 0,4375 & 0,1875 \\
\hline Monday & 0,047 & 0,0937 & 0,3906 & 0,4687 \\
\hline Tuesday & 0,117 & 0,1406 & 0,4023 & 0,3398 \\
\hline Wednesday & 0,085 & 0,1201 & 0,3994 & 0,3955 \\
\hline Tursday & 0,099 & 0,1289 & 0,4001 & 0,372 \\
\hline Friday & 0,093 & 0,1252 & 0,3999 & 0,3817 \\
\hline
\end{tabular}

sufficient daily weather data is obtained varies, but the most dominant weather occurs in one week namely sunny weather with an average probability of above 0.0897 or $8.97 \%$, cloudy with an average probability of above 0.1137 or $11.37 \%$, light rain with an average probability of 0.3828 or $38.28 \%$ and rain 0.4136 or 41.36 . 
C. If it's cloudy on Friday, the weather predictions per day in the next 1 week are $\pi(0)=\left[\begin{array}{llll}0 & 1 & 0 & 0\end{array}\right]$

Table 6. Weather data quite varied

\begin{tabular}{lllll} 
Probability & Bright & Cloudy & Light Rain & Rain \\
\hline Saturday & 0 & 0,25 & 0,5 & 0,25 \\
\hline Sunday & 0,0625 & 0,125 & 0,375 & 0,4375 \\
\hline Monday & 0,1093 & 0,1406 & 0,4062 & 0,3437 \\
\hline Tuesday & 0,0859 & 0,121 & 0,3984 & 0,3945 \\
\hline Wednesday & 0,0986 & 0,1289 & 0,4003 & 0,372 \\
\hline Tursday & 0,093 & 0,1252 & 0,3999 & 0,3818 \\
\hline Friday & 0,0954 & 0,1267 & 0,4 & 0,3777 \\
\hline
\end{tabular}

The daily weather data is quite varied on Table 6, occurring in one week, namely sunny weather with an average probability of 0.0778 or $7.78 \%$, cloudy weather with an average probability of 0.1453 or $14.53 \%$ and light rain with an average probability an average of 0.4114 or $41.14 \%$, and rainy weather with an average probability above 0.3653 or $36.53 \%$.

D. If on a sunny Friday, the weather predictions per day in the next 1 week are $\pi(0)=\left[\begin{array}{llll}1 & 0 & 0 & 0\end{array}\right]$

If on Friday it is sunny, the matrix $(0)=\left[\begin{array}{llll}1 & 0 & 0 & 0\end{array}\right]$ can be presented in tabular form on Table 7.

Table 7. Daily weather Data Quite Varied

\begin{tabular}{lllll}
\hline Probability & Bright & Cloudy & Light Rain & Rain \\
\hline Saturday & 0 & 0 & 0,5 & 0,5 \\
\hline Sunday & 0,125 & 0,125 & 0,375 & 0,375 \\
\hline Monday & 0,0937 & 0,125 & 0,4062 & 0,3828 \\
\hline Tuesday & 0,9375 & 0,125 & 0,3984 & 0,3828 \\
\hline Wednesday & 0,0957 & 0,1269 & 0,4003 & 0,3769 \\
\hline Tursday & 0,0942 & 0,1259 & 0,3999 & 0,3798 \\
\hline Friday & 0,0949 & 0,1264 & 0,4 & 0,3785 \\
\hline
\end{tabular}

Based on the table above, the daily weather data is quite varied, but the most dominant weather occurs in one week, namely sunny with an average probability of above 0.2058 or $20.58 \%$, cloudy with an average probability of above 0,1077 or $10.77 \%$, light rain with an average probability above 0.4114 or $41.14 \%$ and rain with an average probability above 0.3965 or $39.65 \%$.

\section{CONCLUSION}

The results of the discussion in previous chapters can be concluded: The transition matrix for weather changes is obtained as follows:

$$
P=\left[\begin{array}{cccc}
0 & 0 & 0,5 & 0,5 \\
0 & 0,25 & 0,5 & 0,2 \\
0 & 0 & 0,25 & 0,7 \\
0,25 & 0,25 & 0,5 & 0
\end{array}\right]
$$

From the transition matrix above, the Lumajang city weather can be estimated as follows:

a. If today is sunny, tomorrow will have a $25 \%$ chance of sunny weather, $0 \%$ cloudy, $10 \%$ light rain and $10 \%$ rain.

b. If it's cloudy today, tomorrow will have a $0 \%$ chance of sunny, $0 \%$ cloudy, $25 \%$ light rain and $75 \%$ rain.

c. If it rains today, tomorrow it will have a $0 \%$ chance of sunny weather, $25 \%$ cloudy, $0.75 \%$ light rain and $25 \%$ rain.

d. If it rains today, tomorrow it will have a $0 \%$ chance of sunny weather, $0 \%$ cloudy, $50 \%$ light rain and $50 \%$ rain.

Based on the weather change transition matrix above, to predict some of the weather that will occur during the next 1 week, it can be calculated based on the matrix steady state

$$
\pi_{j}=\sum_{i}^{7} \pi_{i} P_{i j}, i=j=1,2,3,4
$$

\section{REFERENCES}

[1] M. Fauzy, K.R. Saleh, I. Asror, Penerapan Metode Association Rule Menggunakan Algoritma Apriori pada Simulasi Prediksi Hujan Wilayah Kota Bandung, (in Indonesian), 2016.

[2] Badan Meteorologi Klimatologi dan Geofisika (BMKG). http://www.bmkg.go.id/. (accessed Dec. 3, 2021).

[3] R.A. Faroh, Penerapan Model Fuzzy Time SeriesMarkov Chain untuk Peramalan Inflasi, (in Indonesian), Malang: UIN Maulana Malik Ibrahim, 2016.

[4] F. Nurhamiddin, F. M. Sulisa, Peramalan cuaca menggunakan metode rantai Markov (Studi Kasus: Rekaman cuaca harian di kantor BMKG Kota Ternate), Jurnal Biosaintek, 2019, 2. 16-22, DOI:

https://doi.org/10.52046/biosainstek.v2i01.312.16$\underline{22}$

[5] S. Nurjana, M. Paendong, Y. Langi, Penerapan rantai Markov dalam pemilihan minat masuk siswa SMA ke Universitas di Indonesia (in Indonesian), 2016, D'cartesian, 5(1). 50, DOI: https://doi.org/10.35799/dc.5.1.2016.12733

[6] B. Hidayah, R. Budhiyati, P. Hendikawati, Aplikasi diagonalisasi matriks pada rantai Markov (in Indonesian), 2014, Unnes Journal of mathematics, 3. $20-24$ 